\title{
Вплив поліморфізмів хемокінів на ефективність хіміотерапії у хворих на Her2/neu-негативний рак грудної залози
}

\author{
Національний інститут раку, Київ \\ Одержано 8.11.2021 \\ Прийнято до друку 29.11.2021 \\ DOI: 10.32471/clinicaloncology.2663-466X.43-3.28300
}

\begin{abstract}
Вступ. На сьогодні ідея персоналізованого лікування кожного окремого пацієнта залежно від суми біологічних характеристик пухлини залишається актуальним питанням клінічної онкології. Пухлинні клітини та клітини мікрооточення синтезують різноманітні хемокіни, які виконують роль факторів росту, стимуляторів ангіогенезу та інвазивності, беруть участь у формуванні імуносупресивного мікрооточення. Мета - вивчити вплив поліморфізму гена C-C рецептора хемокіну 5 (CCR5(del32) на ефективність передопераційної хіміотерапії у хворих на Her2/neu-негативний рак грудної залози при місцево-розповсюдженому раку грудної залози. Матеріали та методи. У дослідження включено 62 пацієнтки з місцево-розповсюдженим РГЗ, що потребували проведення неоад'ювантної хіміотерапії. Результати. Вивчено роль поліморфізму гена С-С рецептора хемокіну 5 (CCR5(del32) в ефективності передопераційної хіміотерапії у 62 хворих на Her2/neu-негативний місцево-розповсюджений РГЗ, що залишається недостатньо вивченою. Висновки. Визначено, що рівень терапевтичного патоморфозу був вищим у пацієнток з генотипом N/del32 за геном CCR5. Проте отримані результати потребують подальшого підтвердження.
\end{abstract}

Ключові слова: рак грудної залози; хемокіни; неоад’ювантна хіміотерапія; ефективність лікування.

\section{встУП}

Відомим фактом є те, що рак грудної залози (РГЗ) є гетерогенною пухлиною. На сьогодні, з урахуванням особливостей експресії маркерних генів, виділяють 4 основних типи РГЗ: люмінальний А, люмінальний Б, Her2-позитивний та тричі негативний. На цій класифікації базується визначення агресивності пухлин та вибір стратегії подальшого лікування пацієнток. Проте навіть у межах одного підтипу існує певна гетерогенність пухлин, які характеризуються своїм прогнозом подальшого перебігу хвороби і чутливістю до певного лікування. Так, тричі негативний РГЗ має щонайменше вісім підтипів, серед яких три - 3 несприятливим прогнозом, три - 3 проміжним та два - зі сприятливим $[1,2]$. Так само пухлини люмінального Б типу поділяють на: люмінальний Б Her2/neu+ та люмінальний Б Her2/neu-, які мають свої особливості у виборі подальшого лікування. У зв'язку із цим набуває актуальності ідея персоналізованого лікування кожного окремого пацієнта залежно від суми біологічних характеристик пухлини. На сьогодні є очевидним, що пухлинні клітини діють не самостійно, а у взаємодії з мікрооточенням пухлини $[3,4]$

Мікрооточення пухлини розглядається як один 3 ключових факторів, що відіграє важливу роль у пухлинній прогресії, а застосування в клінічній практиці методів якісного та кількісного визначення елементів мікрооточення пухлини може сприяти виділенню групи хворих, яким буде показано застосування нових методів лікування та персоніфікації терапії.

Хемокіни - це група низькомолекулярних цитокінів, фізіологічною роллю яких є регуляція міграції імунокомпетентних клітин шляхом хемотаксису [5]. Хемокіни продукуються Т-клітинами, макрофагами та дендритними клітинами. Під час канцерогенезу як пухлинні клітини, так і клітини мікрооточення синтезують різноманітні хемокіни, які виконують роль факторів росту, стимуляторів ангіогенезу та інвазивності, а також беруть участь у формуванні імуносупресивного мікрооточення. Імунна супресія виникає як за рахунок міграції та активації пухлино-асоційованих макрофагів (tumor-associated macrophages), супресорних клітин мієлоїдного походження (myeloid-derived suppressor cells), регуляторних Т-лімфоцитів або мезенхімальних стовбурових клітин, так і за рахунок пригнічення цитотоксичних Т-лімфоцитів. У від- повідь на хемокіни, синтезовані в певному органі чи тканині, пухлини, які експресують відповідний хемокіновий рецептор, швидше прогресують та призводять до утворення віддалених метастазів [6]. Неопластичні тканини містять високі рівні медіаторів запалення, включаючи С-С хемокіновий ліганд 5 (CCL5) і C-C хемокіновий рецептор типу 5 (CCR5), який $\epsilon$ рецептором адгезії $[7,8]$.

Мета дослідження - вивчити вплив поліморфізму гена C-C рецептора хемокіну 5 (CCR5(del32) на ефективність передопераційної хіміотерапії у хворих на Her2/neu-негативний РГЗ при місцево-розповсюдженому раку.

\section{МАТЕРІАЛИ ТА МЕТОДИ ДОСЛІДЖЕННЯ}

У дослідження включено 62 пацієнтки 3 місцево-розповсюженим РГЗ, що потребували проведення неоад’ювантної хіміотерапії (НАХТ). У всіх досліджуваних хворих було застосовано діагностичний клініко-інструментально-лабораторний комплекс досліджень, у тому числі ультразвукове дослідження грудної залози або мамографію, комп’ютерну томографію органів грудної порожнини, органів черевної порожнини та малого таза з контрастним підсиленням з метою об'єктивної оцінки відповіді пухлини на хіміотерапевтичне лікування, яке проводилося відповідно до сучасних вимог (за шкалою RECIST 1.1). Усім хворим було призначено курс НАХТ за протоколом 4 АС (доксорубіцин 60 мг/м² + ендоксан 600 мг/м² в 1-й день), кожен 21-й день, чотири введення; та 12 щотижневих введень Т (паклітаксел 80 мг/м²).

Вік хворих на момент включення в дослідження коливався в межах $28-70$ років. Середній вік $-52,3 \pm 5,1$ року.

Морфологічне дослідження післяопераційного матеріалу виконувалося за стандартною методикою. Препарати фарбувалися гематоксиліном і еозином. Оцінку лікувального патоморфозу виконували на основі визначення об'єму життєздатної залишкової пухлини (ОЖЗП), наявності раку in situ, а також кількості та розмірів уражених лімфовузлів (за класифікацією Miller - Payne). Морфологічні та імуногістохімічні дослідження проводилися в патологоанатомічному відділенні Національного інституту раку МОЗ України (завідувач відділення - кандидат медичних наук М.С. Кротевич). 
Під час дослідження поліморфізму гена CCR5 (del32) ДНК виділяли з периферичної крові за допомогою комерційної тестсистеми «innuPREPBloodDNAMiniKit» (AnalytikJena, Німеччина). Досліджувану ділянку гена ампліфікували за допомогою специфічних праймерів («Metabion», Німеччина) із використанням комерційного набору DreamTaqGreenPCRMasterMix (фірми «ThermoScientific», США). Стан ампліфікованих фрагментів гена аналізували в 3\% агарозному гелі (агароза фірми «CleaverScientific», Великобританія) 3 додаванням бромистого етидію. Для оцінки розміру фрагментів вносили маркер молекулярної маси GeneRuler 50 bpDNALadder («ThermoScientific», США), візуалізували розподіл фрагментів у гелі за допомогою трансілюмінатора. Обробка отриманого зображення проводилася в комп'ютерній програмі Vitran. Результати алельспецифічної полімеразної ланцюгової реакції ділянки гена CCR5 (del32) враховували залежно від довжини наявних ампліфікованих фрагментів - 172 п.н. та/або 140 п.н. За наявності ампліфікованого фрагмента розміром 172 п.н. реєстрували нормальний варіант гена $C C R 5-\mathrm{N} / \mathrm{N}$, фрагменти 172 п.н. та 140 п.н. одночасно свідчили про гетерозиготний стан - N/del32, а при довжині фрагменту 140 п.н. фіксували делеційний поліморфізм у гомозиготному стані del32/del32 (рис. 1).

Молекулярно-генетичне дослідження виконувалося в молекулярно-генетичній лабораторії Державного закладу «Референс-центр з молекулярної діагностики МОЗ України» (завідувач - кандидат біологічних наук 3.I. Россоха).

Обробка отриманих даних виконувалася з використанням пакета програм «Statistica 10.0». Для оцінки розподілу варіантів використовувався дисперсійний аналіз. Для проведення кореляційного аналізу та виявлення різниці між змінними використовували t-критерій Стьюдента та критерій $\chi 2$. Статистично значимими вважалися дані з достовірністю різниці за $\mathrm{p}<0,05$.

\section{ОТРИМАНІ РЕЗУЛЬТАТИ ТА ЇХ ОБГОВОРЕННЯ}

Проаналізовано результати лікування 62 пацієнток з місцево-розповсюдженим РГЗ: 43 пацієнтки мали естрогенопозитивний РГЗ, 19 - естрогенонегативний РГЗ.

Проведене молекулярно-генетичне дослідження у хворих на місцево-розповсюджений РГЗ до лікування виявило генотип N/N за геном CCR5 (del32) у $46(73,8 \%)$ пацієнток, генотип N/del32 за геном CCR5 у $15(24,6 \%)$ пацієнток та генотип del32/del32 за геном CCR5 у $1(1,6 \%)$ пацієнтки (табл. 1).

Варто зазначити, що у пацієнток з ураженням аксилярних лімфатичних вузлів, носіїв генотипу N/N за геном CCR5 (del32), частіше виявляли гормоннезалежні пухлини (естроген рецептор(ER)-негативні, прогестерон рецептор(PR)негативні) (відношення ризиків 3,27 ; довірчий інтервал $1,05-$ $5,49, \mathrm{p}=0,05)$ (табл. 2).

Так, у групі рецептор-негативних пухлин, з наявністю метастазів в аксилярні лімфовузли, генотип N/N за геном CCR5 спостерігався у 88,89\% пацієнток, тоді як генотип $\mathrm{N} / \mathrm{del} 32$ за геном CCR 5 виявлено лише у $11,11 \%$. Проте в групі гормон-залежних пухлин з ураженням лімфовузлів, носіїв алелі N/N за геном CCR5 було лише $71 \%$ порівняно з 88,9\% у пацієнток з рецептор-негативними пухлинами, а носіїв генотипу N/del32 за геном CCR5 виявлено достовірно більше: у $29 \%$ хворих порівняно з $11,1 \%$ у пацієнток з рецептор-негативними пухлинами $(\mathrm{p}=0,05)$. У пацієнток без метастазів у регіонарні лімфатичні вузли не було виявлено асоціації делеційного поліморфізму гена CCR5 з розповсюдженістю процесу та біологічними особливостями пухлини, такими як експресія рецепторів стероїдних гормонів.

Аналізуючи результати НАХТ у пацієнток з місцево-розповсюдженим РГЗ, було встановлено, що середні значення об'єму життєздатної залишкової пухлинної тканини (ОЖЗПТ) у носіїв алелі $\mathrm{N} / \mathrm{N}$ за геном CCR5 становили $52,94 \%( \pm 4,06)$, а у носіїв алелі N/del32 за геном CCR5 - 35,63\% $( \pm 7,37)$.

Таким чином, у хворих з генотипом N/del32 за геном CCR5 після завершення НАХТ ОЖЗПТ був достовірно нижчим порівняно з хворими з генотипом N/N за геном CCR $(\mathrm{p}=0,04)$ (табл. 3, 4, рис. 2).

Нами проаналізовано ефективність НАХТ залежно від експресії рецепторів стероїдних гормонів на пухлинних клітинах пацієнток з РГЗ (табл. 4).

\section{ВИСНОВКИ}

Отже, за результатами нашого дослідження визначено, що рівень терапевтичного патоморфозу був кращим у пацієнток з генотипом N/del32 за геном CCR5: середні значення об'єму життєздатної залишкової пухлини у носіїв алеля N/N за геном CCR5 були 52,94 $\pm 4,06 \%$, а у носіїв алеля $\mathrm{N} / \mathrm{del} 32$ за геном CCR5 - 35,63 \pm 7,37\% (p=0,04). Необхідні

Таблиця 1. Результати молекулярно-генетичного дослідження поліморфізму гена CCR5 (del32) у хворих на місцево-поширений РГЗ

\begin{tabular}{lc}
\hline \multicolumn{1}{c}{ Показник } & Кількість пацієнток, n (\%) \\
\hline Поліморфізм гена CCR5 (del32) & \\
-N/N & $46(73,8)$ \\
-N/del32 & $15(24,6)$ \\
-генотип del32/del32 & $1(1,6)$ \\
\hline
\end{tabular}

Таблиця 2. Особливості поліморфізму гена $C C R 5$ (del32) у хворих на РГЗ з ураженням регіонарних лімфовузлів

\begin{tabular}{lccccc}
\hline Eкспресія ER & \multicolumn{2}{c}{ Генотип NN } & \multicolumn{2}{c}{ Генотип $\mathbf{N} / \mathbf{d e l 3 2}$} & $\begin{array}{c}\text { Загальна } \\
\text { кількість ви- } \\
\text { падків }\end{array}$ \\
\hline ER- & $\mathbf{n}$ & $\%$ & $\mathbf{n}$ & $\%$ & 9 \\
ER + & 8 & 88,89 & 1 & 11,11 & 91 \\
Усього & 22 & 70,97 & 9 & 29,03 & 30 \\
\hline
\end{tabular}

Таблиця 3. ОЖЗПТ після завершення НАХТ залежно від поліморфізму гена CCR5 (del32) у хворих на РГЗ

\begin{tabular}{|c|c|}
\hline CCR5 (del32) генотип & $\begin{array}{c}\text { ОЖЗПТ, } \\
\text { середнє значення ( } \pm \text { SD) }\end{array}$ \\
\hline$-\mathrm{N} / \mathrm{N}$ & $52,94 \%( \pm 4,06)$ \\
\hline$-\mathrm{N} /$ del32 & $35,63 \%( \pm 7,37)$ \\
\hline -del32/del32 & $0,0 \%$ \\
\hline
\end{tabular}

Таблиця 4. ОЖЗПТ після завершення НАХТ залежно від експресії рецепторів стероїдних гормонів у хворих на РГЗ

\begin{tabular}{|c|c|c|c|}
\hline ER-статус & $\begin{array}{c}\text { Кількість пацієн- } \\
\text { тів, } \mathbf{n}\end{array}$ & $\begin{array}{c}\text { ОЖЗПТ, \% } \\
\text { (середнє значення) }\end{array}$ & p \\
\hline ER- & 19 & 44 & \multirow{2}{*}{0,047} \\
\hline $\mathrm{ER}+$ & 43 & 50 & \\
\hline
\end{tabular}

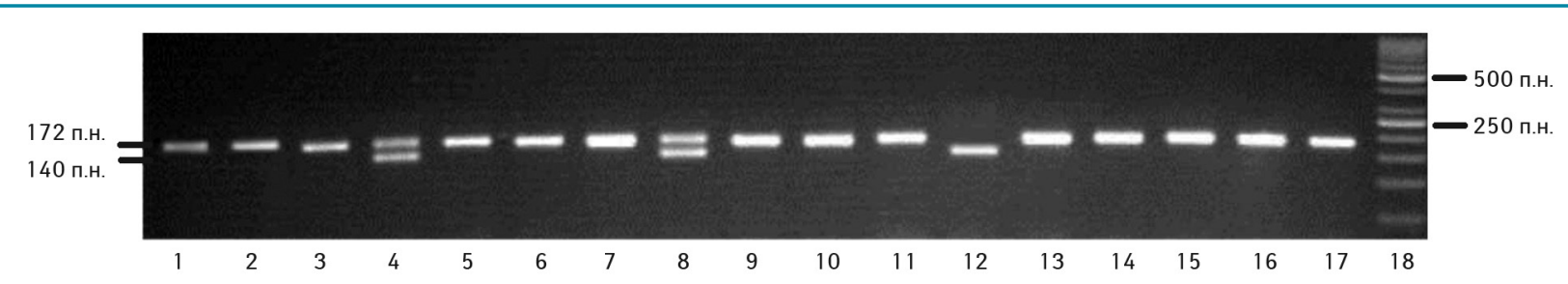

Рис. 1. Електрофореграма розподілу ампліфікованих фрагментів гена CCR5 del32. 3разки 1-3, 5-7, 9-11, 13-17 - генотип N/N, зразки 4, 8 - генотип N/del32, зразок 12 - генотип del32/del32, 18 - маркер молекулярної маси 


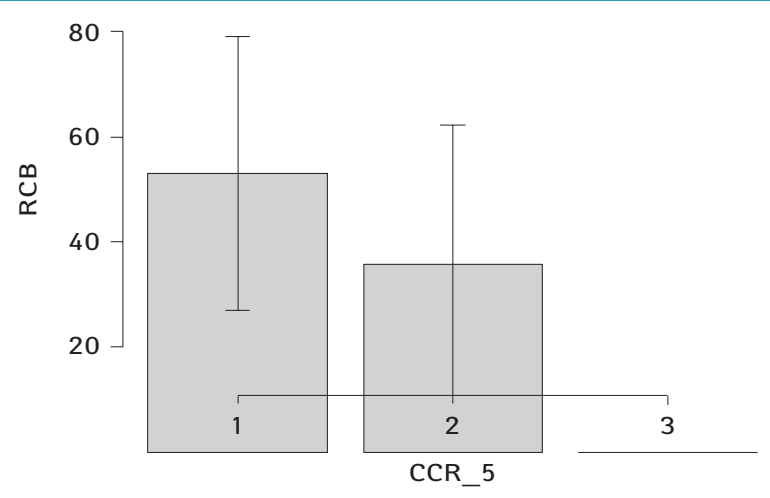

Рис. 2. ОЖЗПТ після завершення НАХТ залежно від поліморфізму гена CCR5 (del32) у хворих на РГЗ.1 - генотип N/N за геном CCR5 (del32); 2 - генотип N/del32 загеном CCR5(del32);3 - генотип del32/del32 загеном CCR5(del32)

подальші дослідження впливу поліморфізму хемокінів на віддалені результати лікування хворих на РГЗ.

\section{СПИСОК ВИКОРИСТАНОї ЛІТЕРАТУРИ}

1. Perou, C. M. (2000). Molecular portraits of human breast tumors. Nature, 406 , 747-752. doi: $10.1038 / 35021093$

2. Hudis, C., \& Gianni, L. (2011). Triple negative breast cancer: an unmet medical need. The oncologist, 28 (2), 135-146. doi: 10.1634/theoncologist.2011-S1-01.

3. Tsai, M. J., Chang, W. A., Huang, M. S., \& Kuo, P. L. (2014). Tumor Microenvironment: A New Treatment Target for Cancer. ISRN Biochemistry, 351959 doi: 10.1155/2014/351959

4. Andre, F., Dieci, M., Dubsky, P., Sotiriou, C., Curigliano, G., Denkert, C., \& Loi, Sh. (2012). Molecular Pathways: Involvement of Immune Pathways in the Therapeutic Response and Outcome in Breast Cancer. Clinical Cancer Research, 19(1), 28-33. doi: 10.1158/1078-0432.CCR-11-2701.

5. Aldinucci, D., \& Colombatti, A. (2014). The Inflammatory Chemokine CCL5 and Cancer Progression, Mediators of Inflammation, 2014, 292376. doi $10.1155 / 2014 / 292376$

6. Aldinucci, D., Borghese, C., \& Casagrande, N. (2020). The CCL5/CCR5 Axis in Cancer Progression. Cancers, 12, 1765. doi.10.3390/cancers12071765.

7. Gao, D., Rahbar, R., \& Fish, E. N. (2016). CCL5 activation of CCR5 regulates cell metabolism to enhance proliferation of breast cancer cells. Open Biology, 6, 160122 doi.10.1098/rsob.160122.

8. Xiang, P., Jin, S., Yang, Y., Sheng, J., He, Q., Song, Y., ... Jin, J. (2019). Infiltrating CD4+ T cells attenuate chemotherapy sensitivity in prostate cancer via CCL5 signaling. Prostate, 79(9), 1018-1031. doi: 10.1002/pros.23810.

\section{Effect of chemokin polymorphisms on the efficacy} of chemotherapy in patients with Her2/neunegative breast cancer

L. Syvak, N. Verovkina, S. Lyalkin, T. Tarasenko, O. Martyniuk National Cancer Institute, Kyiv

Summary. Abstract. Today, the idea of personalized treatment of each individual patient depending on the sum of the biological characteristics of the tumor remains a topical issue in clinical oncology. Tumor cells and cells of the microenvironment synthesize various chemokines that act as growth factors, stimulators of angiogenesis and invasiveness, participate in the formation of immunosuppressive microenvironment. Aim - to study the CCR5 (del32) gene polymorphism in patients with locally advanced breast cancer (LABC) of various molecular subtypes and its effect on the effectiveness of perioperative chemotherapy. Materials and methods. Treatment results of 62 patients with breast cancer stages T1$3 \mathrm{~N} 0-3 \mathrm{M} 0$ treated with neoadjuvant chemotherapy were evaluated. Results. The role of chemokine receptor $C C$ gene polymorphism (CCR5) (del32) in the efficacy of preoperative chemotherapy in 62 patients with Her2/neu-negative locally advanced breast cancer has been insufficiently studied, genome CCR5. However, the results obtained require further research. Conclusions. The level of therapeutic pathomorphosis after perioperative chemotherapy was better in carriers of $\mathrm{N} /$ del132 genotype of CCR 5 gene compared with the carriers of $\mathrm{N} / \mathrm{N}$ genotype of $C C R 5$ gene $(\mathrm{p}=0,04)$. The one patient with del132/del132 genotype achieved a pCR after perioperative chemotherapy.

Key words: breast cancer; hemokines; neoadjuvant chemotherapy; treatment efficacy.

Адреса:
Верьовкіна Наталія Олегівна
03022, Київ, вул. Ломоносова, 33/43
Національний інститут раку
$\begin{aligned} & \text { E-mail: 15a78nataliia@gmail.com } \\ & \text { Correspondence: } \\ & \text { Verovkina Natalia } \\ & \text { 33/43 Lomonosova Str., Kyiv 03022 } \\ & \text { National Cancer Institute } \\ & \text { E-mail: 15a78nataliia@gmail.com }\end{aligned}$

